\title{
Agent or Borrower? An Incentive of Moral Hazard with China Commercial Guarantee Company
}

\author{
Feng He, ${ }^{1,2}$ Wei Zhang, ${ }^{1,2}$ Yongjie Zhang, ${ }^{1,2}$ and Xiong Xiong ${ }^{1,2}$ \\ ${ }^{1}$ College of Management and Economics, Tianjin University, Tianjin 300072, China \\ ${ }^{2}$ China Center for Social Computing and Analytics, Tianjin University, Tianjin 300072, China \\ Correspondence should be addressed to Yongjie Zhang; yjz@tju.edu.cn
}

Received 26 December 2013; Accepted 16 February 2014; Published 23 March 2014

Academic Editor: Fenghua Wen

Copyright (c) 2014 Feng He et al. This is an open access article distributed under the Creative Commons Attribution License, which permits unrestricted use, distribution, and reproduction in any medium, provided the original work is properly cited.

\begin{abstract}
This paper studies the behavior of commercial guarantee company in the game theory framework. Different payoff structures with guarantee company behavior for banks, borrowers, and the guarantors are formed in the presence of credit rationing. We derived and explained the surviving rule of different types of guarantee companies, and we further conclude the condition in which guarantee companies are likely to be involved in a moral hazard problem. We conclude that, in the presence of regulatory arbitrage opportunity, the guarantee company has incentive to switch its role from bank agent to the borrower, being a second-hand lender. When the macroeconomic risk is high, the switching of this role will transfer the risk back to the banks.
\end{abstract}

\section{Introduction}

Financing difficulties for SMEs are a worldwide problem. Over the past twenty years, China has experienced a rapid economic growth. SMEs constitute over 90 percent of the total enterprises in China and offer the majority of job vacancies (National Bureau of Statistics). In order to increase credit availability, the guarantee companies are introduced into the financial system to alleviate the difficulty of SMEs in obtaining bank loans [1]. However, it is generally considered that commercial guarantee company in China is highly risky and somehow is related to informal lending. A lot of news and reports expose that the guarantee companies are cheating for loans together with other bank borrowers. Stated by the president of China Banking Regulatory Commission, "3000 billion of bank credit money flows into the shadow banking system, and the guarantee company plays a significant role in this business."

SMEs have been described as "the most important engines of economic growth and job-creation in transition economies as well as in other developing and developed economies, including those of the OECD countries" (OECD, 2000). A credit guarantee is a financial product that a small entrepreneur can buy as a partial substitute for collateral. It is a promise by a guarantor to pay all or part of the loan if the borrower defaults [2]. However, most of China guarantee companies afford 100 percent risk, whilst banks seldom afford any risk together with the guarantee company. SMEs credit guarantee company in China just started a few years, and, in the credit rationing situation, loan supply is far away from demand satisfaction [3-5]. Research on the China financial system discovered that the financial system is dominated by a large but inefficient banking sector [6], and Ayyagari argues that alternative financing and governance mechanisms support China's growth [7].

Credit guarantee schemes emerge typically for three reasons: differential information, spreading and diversifying risk, or regulatory arbitrage [8]. Most of the guarantee scheme is operated by the government all around the world, except a few countries like China [9]. The question which rose was what is the reason for China guarantee companies to exist? Philip et al. [9] analyzed the data from one of the top three China guarantee companies and discovered that credit guarantee officer's assessment of loan risk was negatively related to bank loan rate. There are also some researchers who suggested the phenomenon of "lazy guarantor." Manove et al. considered that the guarantee companies' risk control relies too much on the collateral [10]. However, others argue 
TABLE 1: Payoff structure of bank and borrower.

\begin{tabular}{lccc}
\hline & Bank & Borrower & Total payoff \\
\hline$R \geq L(1+i)-C$ & $L(1+i)$ & $R-L(1+i)$ & $R$ \\
$R<L(1+i)-C$ & $R+C$ & $-C$ & $R$ \\
\hline
\end{tabular}

that the correlation between collateral and default risk is ambiguous [11, 12]. Discussions regarding the role and the effect of guarantee companies also cause research concern [13-16].

Our incentive is to study how commercial guarantee companies operate in China and what role do they play. It is argued that companies providing guarantees play two roles: one is the SME and the other is the financial counterparty (European Commission, 2006). In this paper, we use game theory framework to discuss why commercial guarantee companies in China are risky and how they can survive. Furthermore, we model and explain the incentive of moral hazard problem of commercial guarantee companies.

\section{Characteristics of Commercial Guarantee Companies in China}

In China, a lot of guarantee companies had emerged over the last five years before government regulated this industry, and many went bankruptcy after the regulation enforcement. Lacking strict law environment and industry monitoring authority in China, guarantee companies tend to exist in the beginning for regulation arbitrage, and later some died out as the arbitrage opportunity vanished. As modeled and proved by many scholars, high risk should correspond with high return in stock market $[17,18]$; it also holds for guarantee company being a profit maximizer. Investigating the role of guarantee company played in the credit chain can offer a solution to policy makers on how to regulate the industry to ensure the benign development.

We will first consider the payoff structure for banks and borrowers in the traditional credit rationing framework. In the absence of guarantor position, the banks take full risk of borrowers' default.

Suppose the bank lending amount is $L$ with interest rate $i$; collateral $C$ is offered by the borrower. At the time of repayment, the borrowers obtain $R$ for their investment return. If $R$ is larger than the borrowed amount and promised interest minus the collateral value, being a profit maximizer, the borrower will repay bank loan and the bank will get the money back as well as the interest. In the case of the borrowers' investment failure, the borrower will lose his collateral and the bank will keep all residual investment revenues as well as the collateral. The payoff structure is as in Table 1 [19].

When the guarantee company takes the guarantor position, a guarantee fee $L g$ is involved, where $g$ denotes guarantee rate. Normally, $\mathrm{Lg}$ is realized in the beginning of the business. The guarantee company has security deposit $G$ for its guarantor position and will lose it in the case of borrower's default. In practical, if the guarantee company does not go

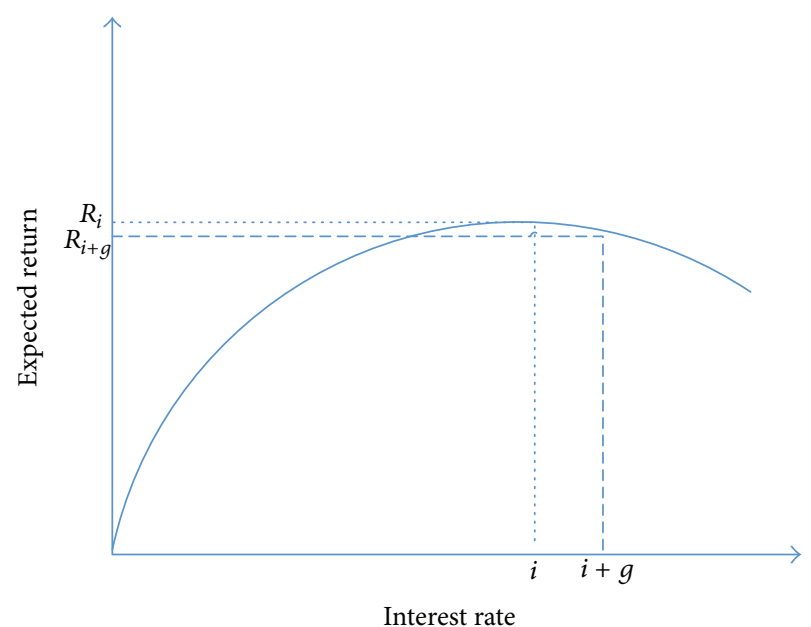

Figure 1: Interest rate and excepted return.

bankrupt, it will help the borrower to repay the loan and take over the collateral even when suffering losses, because every guarantee company has its fame and creditworthiness. Banks and rating agency will consider borrower's default rate that the company takes the guarantor position according to granting the guarantee company's credit. Thus, in order to keep good relationship with banks to obtain credit, the guarantee company will always help the borrower to pay back the loan as long as there is sound capital reverse.

The payoff structure with a guarantee company is as in Table 2.

We assume the collateral provided by the borrower can be transfered directly to the guarantee company, ignoring the value discounted in the process.

There are three circumstances: the borrower repays the promised amount; the borrower defaults but the guarantee company repays the promised amount; both the borrower and the guarantee company default.

In the first circumstance, the cost for the borrower is the interest rate and the guarantee rate. In the final state, the bank gets back the principle and interest while the guarantee company earns the guarantee fee corresponding with its guaranteed amount. In the second circumstance, the borrower defaults and loses his collateral; meanwhile the guarantee company compensates for the borrower and pays the shorting money between the borrowers promised amounts. The third circumstance represents the borrower default and the guarantee company goes bankruptcy, where the borrower loses the collateral and the guarantee company loses all its security deposit.

In the guarantee framework, the borrower's cost increases from $L i$ to $L(i+g)$, and the expected return actually decreases (see Figure 1).

Proposition 1. If guarantee companies' evaluation of borrowers is identical to banks, the combined risk will be higher than the banks offering credit directly; thus, the total expected return from the borrowers will be lower. 
TABle 2: Payoff structure of bank, borrower, and guarantee company.

\begin{tabular}{|c|c|c|c|c|}
\hline & Bank & Borrower & Guarantee company & Total payoff \\
\hline$R \geq L(1+i+g)-C$ & $L(1+i)$ & $R-L(1+i+g)$ & $L g$ & $R$ \\
\hline$L(1+i)-C-G-L g \leq R<L(1+i)-C-L g$ & $L(1+i)$ & $-C-L g$ & $R+C+L g-L(1+i)$ & $R$ \\
\hline$R \geq L(1+i)-C-G-L g$ & $R+C+G$ & $-C$ & $-G$ & $R$ \\
\hline
\end{tabular}

TABLE 3: Payoff structure with extra collateral.

\begin{tabular}{|c|c|c|c|c|}
\hline & Bank & Borrower & Guarantee company & Total payoff \\
\hline$R \geq L(1+i+g)-C-C_{2}$ & $L(1+i)$ & $R-L(1+i+g)$ & $\operatorname{Lg}$ & $R$ \\
\hline$L(1+i)-C-G-L g-C_{2} \leq R<L(1+i)-C-L g-C_{2}$ & $L(1+i)$ & $-C-C_{2}-L g$ & $R+C+C_{2}+L g-L(1+i)$ & $R$ \\
\hline$R \geq L(1+i)-C-G-L g$ & $R+C+G$ & $-C-C_{2}$ & $-G+C_{2}$ & $R$ \\
\hline
\end{tabular}

If the guarantee company does not go bankrupt, the bank will not suffer any loss from the borrower, and it keeps the same profit. So the risk for the bank in underwriting the loan transferred from the probability of borrower's investment failure to the probability of the guarantee company's bankruptcy, which is considered much lower for banks.

Let $R$ be gross returns, and $\theta$ denotes risk. Distribution $F(R, \theta)$ follows mean preserving spread: if two projects have the same expected return but $\theta_{1}>\theta_{2}$, then $\theta_{1}$ is considered a riskier project.

For a given interest $i$, the expected return of the borrowers will be maximized; for a higher interest $(i+g)$, the total return for banks and guarantee companies will be lower; $L_{1}=R_{1}-R_{i+g}$. As the banks profit is not affected, this means that the expected return for the guarantee company will be negative. So the guarantee company's real expected return is its guarantee fee minus its expected loss in the combined expected return with banks. In this case, the guarantee company's risk is $\theta_{L(1+i+g)}$, which is higher than $\theta_{L g-L_{1}}$ corresponding with the expected return $L g-L_{1}$. In other words, the guarantee company suffers additional risk transferred from banks, leading to great asymmetric in the risk and expected return.

From Proposition 1, it is easy to conclude that guarantee companies which are identical to banks can hardly earn profit, and even if they were profitable, commercial guarantee companies will not have any incentive to do so because of the lacking of risk premium. From this point of view, the guarantee company should exist in the form of government or policy supported organizations, leading to risk diversification for banks; in the meantime, guarantee companies get their risk compensation through government direct financial support. The incentive for the government to do so is sacrificing certain economic benefit to increase credit availability.

For commercial guarantee companies, they should have their own evaluation method to distinguish themselves from banks in order to earn profit; namely, if their guarantee fee stays the same, the company should have information superiority or monitoring mechanism to avoid borrower's adverse selection effect or moral hazard. In this case, the guarantee company keeps the same guarantee fee but the default risk is reduced, which will increase the total expected return. Being a third party financial institution, guarantee companies do not offer credit directly, but they usually have more bargain power than SMEs and can easily establish closer relationship with SMEs than banks.

In some circumstances, the guarantee company can recognize more kinds of assets as collateral and usually requires borrowers to provide as much collateral as possible. Suppose the borrower can provide an extra collateral $C_{2}$; then the payoff structure is as in Table 3 .

Proposition 2. The "lazy guarantor" focuses on the collaterals rather than the debt repayment. When the collaterals $C_{2}$ are sufficiently large, the guarantee company will consider the borrower a safe borrower as its expected loss is fully covered by the collaterals.

In this case, if the borrower does not default, both the bank and the guarantor will keep their profit. If the borrower defaults, the guarantee company can dispose its collateral for repayment since it has already fully covered the borrowed amount. The "lazy guarantor" always prefers more collaterals to less. Comparing the payoff structure of extra collaterals with the previous one, it is obvious to conclude that, in the presence of $C_{2}$, keeping all other conditions unchanged, the probability of borrower default will be lower; in case the borrower defaults, the loss suffered by the guarantee company is less.

In both situations above, the role of the guarantee company is to diversify the risk of banks. We can consider the guarantee company as the bank agent for selecting and monitoring the borrower. Through the following proposition, we will study the other role of commercial credit guarantee company as a second-hand lender.

Proposition 3. In the absence of strict regulations, the guarantee company may switch its role from bank's agent to the borrower's side, becoming the connect channel between bank credit market and the shadow banking system.

The commercial guarantee company is an organization chasing for profit. Some of guarantee companies consider the safety of the loan in the first place while others are a profit maximizer. The informal lending channel usually offers more choice for the borrower, that is, flexible lending period 
and requirement. However, the interest rate is usually higher. As a result, we consider that there are regulatory arbitrage opportunities, because the guarantee companies can take cheap money from the bank and lend it out at a higher interest rate in the not well-regulated shadow banking market (see Figure 2). The explanation and operation in practice are as follows.

We will now focus on the borrower side. In China, laws and regulations for lending behavior between companies are not strictly defined; companies can obtain loan through informal lending. Most SMEs in China have difficulties in getting direct finance through banking system as credit is rationed, so there is extra money demand at interest $i$; even when guarantee company is involved, at interest $i+g$, there is still extra money demand $Z_{2}$. The market equilibrium exists when money supply equals demand, and thus the market interest rate $i_{m}$ is formed. If $i_{m}$ is large enough, in other words if $i_{m}$ is significantly larger than $i+g$, there will be an opportunity to borrow money at interest rate $i+g$ and lend out at $i_{m}$ (see Figure 3 ). As banks are weak in monitoring the actual usage of loans, the borrowers thus have opportunities in switching the usage of the loan, which encourage them to find a financial institution which can help them to obtain loans as well as lending it out again.

From the guarantee company side, as stated in Propositions 1 and 2, the guarantee company is always seeking extra return or an alternative way to diversify risk. In practical, the guarantee company needs to deposit a certain amount of money in the bank for its guarantor position. As guarantee companies usually have more bargain power, they will require the borrower to sign some disclosure agreement, most of which include a certain amount of security deposit and investing in an assigned guarantor related company. In both of these ways, the guarantee companies will not keep the money in their bank account and will use it for lending to earn extra money.

From the theoretical point, we can consider the behavior of the guarantee company as constructing a portfolio to balance its return and risk. As stated in the above propositions, the major problems of commercial guarantee company are imbalance in risk and return. As credit is rationed and the market has not been cleared, there are always some borrowers who wish to borrow money below market clear rate, but maybe riskier.

Normally, three kinds of borrowers are willing to cooperate with guarantee company: firstly, companies who cannot obtain credit directly from the banks are obliged to accept the guarantee company's offer in order to get external finance by bank loans. Secondly, large companies that can get loans from banks but do not have proper or urgent use may find a way to make good use of the money. They may invest into the guarantee company for high promised fixed return and relative low risk since the guarantee company has good relationship with banks. Thirdly, there are risk loving borrowers seeking extra profit who abandon the original usage of the loan.

If the guarantee company and the borrower form an economic union, the payoff structure will be changed as in Table 4.
The borrower and guarantee company get a loan $L$ from the bank, the borrower keeps $L_{2}$ while he/she invests $L_{1}$ in the guarantee company, and the borrower's own project success probability is $p_{B}$. The guarantee company has some projects with return $r_{1}\left(i \leq r_{1} \leq i_{m}\right)$ and success probability $p_{g}$. The borrower will only afford the interest and guarantee fee cost of $L_{2}$. In the first situation, both the borrower and the guarantee company succeed in their projects; then the borrower's cost is lower as the cost of $L_{1}$ is afforded by the guarantee company. At the same time, the guarantee company can keep the profit of $L_{1}$ investment. This situation is similar to the government support type, that the guarantee company can have an extra profit to balance risk and return. The second situation involves default of the borrower. In this case, the guarantee company kept part $L_{1}$ can understand as collateral for the loan $L$, which decreases the underlying loss. In the third situation when both borrower and guarantee company default, it is the same case with the payoff structure in Proposition 2. For the last circumstance, only the borrower default is a little tricky to find the loss for the borrowers and the bank. As borrowers only get money of $L_{2}$, they are not willing to repay the full loan and thus this leads to the bad debt for banks; however, if the borrowers wish to keep good records with banks, their maximum loss is $L_{1}$ that goes into the guarantee company. Usually, a guarantee company's bankruptcy involves lots of bad debts which may lead to a big liquidity shock to banks.

\section{Results and Discussion}

Focusing on the guarantee companies, the payoff structure of being agent or borrower is as in Table 5 .

From the matrix, we can study the guarantee company's strategy. When the borrower succeeds in his investing project, the guarantee company can get its guarantee fee as the bank agent. If the guarantee company keeps parts of the loan to be a second-hand lender, the guarantee company will afford the risk of that loan, with probability $p_{g}$ to get a return $L_{1} r_{1}$ or with probability $1-p_{g}$ to lose the principle $L_{1}$. Being a profit maximizer, the guarantee company will choose to switch to the borrower side if

$$
p_{g} L_{1} r_{1}+\left(1-p_{g}\right)\left(-L_{1}\right)>0 \longrightarrow p_{g}\left(r_{1}+1\right)>1
$$

The equation indicates that if the probability of the project success and its return is sufficiently high, the guarantee company will cooperate with borrowers.

If the borrower defaults, it is easy to prove that $L_{1}+$ $\left[p_{g} L_{1} r_{1}+\left(1-p_{g}\right)\left(-L_{1}\right)\right] \geq 0$ always holds, so, in order to prevent loss, the guarantee company would always stand on the borrower side.

We now suppose the probability of project success to indicate the macroeconomic risk. If the success probability is very high, then the market risk is low [20]. Thus, $p_{B}$ and $p_{g}$ are actually correlated. When the borrower's project is very likely to succeed, the guarantor's second-hand loan is also in relative low risk, which encourages the guarantee company to be a borrower instead of bank agent. 


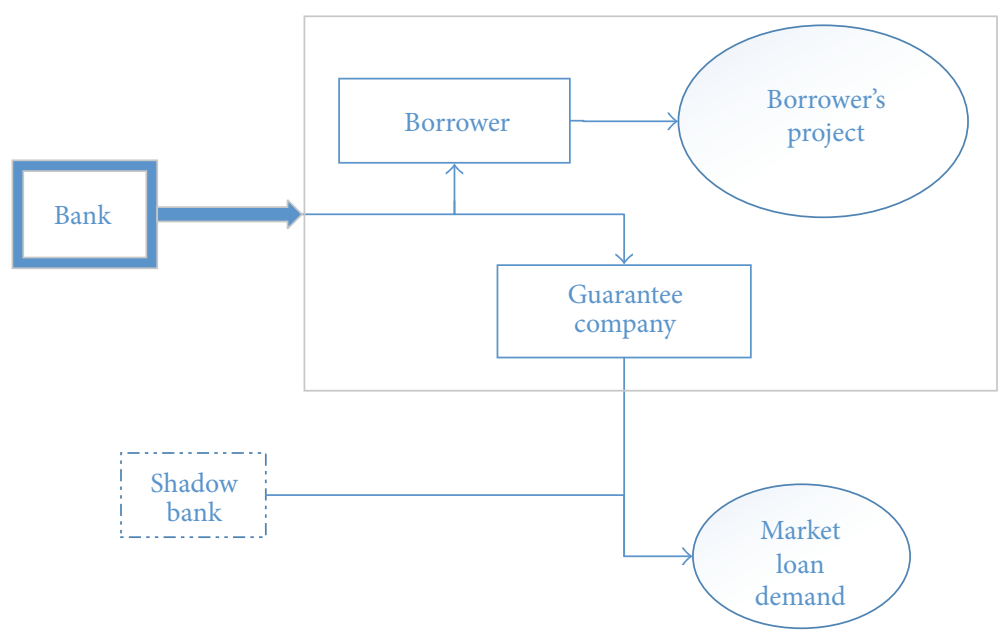

FIGURE 2: Money flow form credit market to informal lending.

TABLE 4: Payoff structure for guarantee company as borrower.

\begin{tabular}{lccc}
\hline Probability & Bank & Borrower & Guarantee company \\
\hline$p_{B} * p_{g}$ & $L(1+i)$ & $R_{2}-L_{2}(1+i+g)$ & $L_{2} g+L_{1}\left(r_{1}-i\right)$ \\
$\left(1-p_{B}\right) * p_{g}$ & $L(1+i)$ & $-C-L_{2} g$ & $R_{2}+C+L_{1} r_{1}+L_{2} g-L(1+i)$ \\
$\left(1-p_{B}\right) *\left(1-p_{g}\right)$ & $R+C+G$ & $-C-L_{2} g$ & $-G+L_{2} g$ \\
$p_{B} *\left(1-p_{g}\right)$ & $\leq L-L_{2}-G$ & $\leq L_{1}$ & $-G+L_{2} g$ \\
\hline
\end{tabular}

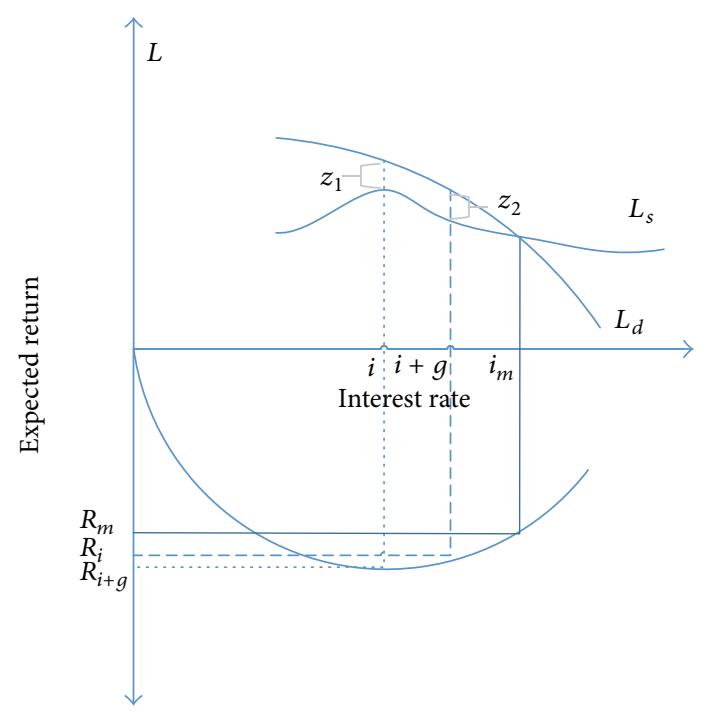

FIGURE 3: Market interest rate and return.

\section{Conclusions}

We study an incentive of moral hazard problems for commercial guarantee companies. The background for China commercial guarantee company is that the guarantee company normally affords full risk, which is significantly different from USA or European countries. Thus, banks, borrowers, and guarantee companies have different aims which result in different behavior. The guarantee companies can survive mainly through the following four ways.

(1) They obtain financial support from government. Banks usually have their own risk control standard and require a third party financial institution for risk diversification. Government supported guarantee companies are usually nonprofitable and mainly for increasing credit availability for SMEs.

(2) They have information advantages. The information is not for finding borrowers but about how to select good borrower. Banks usually focus more on "hard information" based on balance sheet, and guarantee companies can help banks to obtain "soft information" and take responsibility of this information through a guarantor position.

(3) They dispose the collaterals. The "lazy guarantor" gets the assets from borrowers as montages, only if they can dispose for cash which can help the guarantor avoid loss from borrowers default.

(4) In the absence of strict law and regulation environment for guarantee companies, moral hazard problems might occur: the guarantee company may cheat for getting credit from banks together with other borrowers and becomes the second-hand lender afterwards to get excessive return.

We abstract the payoff structure in different circumstances in equilibrium. For the first three guarantee company types, the principle is to balance risk and return. We can observe from the payoff structure that these methods either 
TABle 5: Payoff structure of guarantee company's choice.

\begin{tabular}{lcc}
\hline & Success $\left(p_{B}\right)$ & Fail $\left(1-p_{B}\right)$ \\
\hline Agent & $L g$ & $R+C+L g-L(1+i)$ \\
Borrower & $L g+\left[p_{g} L_{1} r_{1}+\left(1-p_{g}\right)\left(-L_{1}\right)\right]$ & $R+C+L g+L_{1}+\left[p_{g} L_{1} r_{1}+\left(1-p_{g}\right)\left(-L_{1}\right)\right]-L(1+i)$ \\
\hline
\end{tabular}

reduce the loss amount when borrower defaults or lower the default probability by increasing the borrower's default cost. In the last circumstance, it is a very typical story of China guarantee company in practice, and, in the recent years, several such kinds of guarantee companies have been exposed by the newspapers and other media, which caused great loss to banks, that is, HuaDing Credit Guarantee Company, which is the biggest guarantee company of Guangdong province in China. Especially, before 2010 China Regulation for Commercial Guarantee Company, a lot of guarantee companies are established to bridge the bank credit with informal lending, which can exceed interest cap for bank.

However, from the view of the bank, higher collateral may induce the borrower to take excessive risk, which may lead to higher return when success happens but with a greater probability of failure [21]; thus the actual effect of the risk of "lazy guarantor" still needs to be specified.

From our analysis of the guarantee modes, government should provide more support to balance guarantee company's risk and return. Moreover, regulations should be made to avoid regulatory arbitrage.

\section{Conflict of Interests}

The authors declare that there is no conflict of interests regarding the publication of this paper.

\section{Acknowledgments}

The authors are extremely grateful to the editor and the anonymous reviewers for their constructive and valuable comments, which have contributed much to the improvement of this paper. This paper is sponsored by the support of NSFC (Project no. 71341006), the Key Projects in the National Science and Technology Pillar Program (2012BAH31F04), and the Key Project in Tianjin Education Bureaus Social Science Program (2011ZD008).

\section{References}

[1] T. Beck, L. F. Klapper, and J. C. Mendoza, "The typology of partial credit guarantee funds around the world," Journal of Financial Stability, vol. 6, no. 1, pp. 10-25, 2010.

[2] L. Deelen and K. Molenaar, Guarantee Funds for Small Enterprises: A Manual for Guarantee Fund Managers, International Labour Organization (ILO), 2004.

[3] R. Cressy, "Funding gaps: a symposium," Economic Journal, vol. 112, no. 477, pp. F1-F16, 2002.

[4] X. Xiong, Y. Chuanwei, and Z. Yongjie, "Analysis of scale in SME joint guarantee loans using agent-based computational experiment finance," Journal of Management Science in China, vol. 16, no. 3, pp. 88-94, 2013 (Chinese).
[5] Z. Wei and Q. Yong, "Portfolio default risk of multi-bank debt," Journal of Management Science in China, vol. 11, no. 4, pp. 134145, 2008 (Chinese).

[6] F. Allen, J. Qian, and M. Qian, "Law, finance, and economic growth in China," Journal of Financial Economics, vol. 77, no. 1, pp. 57-116, 2005.

[7] M. Ayyagari, A. Demirgüç-Kunt, and V. Maksimovic, "Formal versus informal finance: evidence from China," Review of Financial Studies, vol. 23, no. 8, pp. 3048-3097, 2010.

[8] J. Mikael, "Performance of credit guarantee schemes (CGS)," Working Paper, 2009.

[9] H. D. Philip, C. S. Susan, and Y. T. Dragon, "Does informal finance help formal finance? Evidence from third party loan guarantees," Working Paper, 2011.

[10] M. Manove, A. J. Padilla, and M. Pagano, "Collateral versus project screening: a model of lazy banks," RAND Journal of Economics, vol. 32, no. 4, pp. 726-744, 2001.

[11] A. N. Berger, W. Scott Frame, and V. Ioannidou, "Tests of ex ante versus ex post theories of collateral using private and public information," Journal of Financial Economics, vol. 100, no. 1, pp. 85-97, 2011.

[12] R. Inderst and H. M. Mueller, "A lender-based theory of collateral," Journal of Financial Economics, vol. 84, no. 3, pp. 826-859, 2007.

[13] F. Bartoli, G. Ferri, P. Murro, and Z. Rotondi, "Bank-firm relations and the role of Mutual Guarantee Institutions at the peak of the crisis," Journal of Financial Stability, vol. 9, no. 1, pp. 90-104, 2013.

[14] M. Cowling, "The role of loan guarantee schemes in alleviating credit rationing in the UK," Journal of Financial Stability, vol. 6, no. 1, pp. 36-44, 2010.

[15] B. R. Craig, W. E. Jackson III, and J. B. Thomson, "Small firm finance, credit rationing, and the impact of SBA-guaranteed lending on local economic growth," Journal of Small Business Management, vol. 45, no. 1, pp. 116-132, 2007.

[16] S. Zecchini and M. Ventura, "The impact of public guarantees on credit to SMEs," Small Business Economics, vol. 32, no. 2, pp. 191-206, 2009.

[17] F. Wen and X. Yang, "Skewness of return distribution and coefficient of risk premium," Journal of Systems Science \& Complexity, vol. 22, no. 3, pp. 360-371, 2009.

[18] H. Chuangxia, G. Xu, C. Xiaohong, and W. Fenghua, "Measuring and forecasting volatility in Chinese stock market using HAR-CJ-M model," Abstract and Applied Analysis, vol. 2013, Article ID 143194, 13 pages, 2013.

[19] G. Dell'Ariccia and R. Marquez, "Lending booms and lending standards," Journal of Finance, vol. 61, no. 5, pp. 2511-2546, 2006.

[20] V. Acharya and H. Naqvi, "The seeds of a crisis: a theory of bank liquidity and risk taking over the business cycle," Journal of Financial Economics, vol. 106, no. 2, pp. 349-366, 2012.

[21] J. E. Stiglitz and A. Weiss, "Credit rationing in markets with imperfect information," The American Economic Review, vol. 71, pp. 393-410, 1981. 


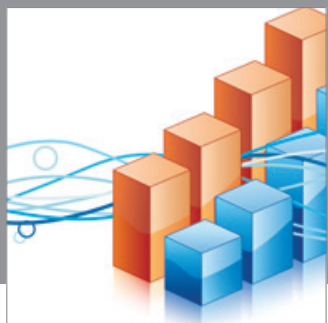

Advances in

Operations Research

mansans

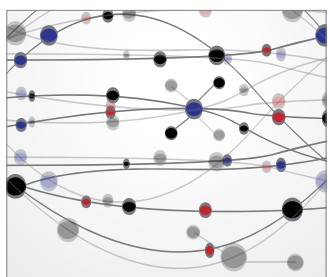

The Scientific World Journal
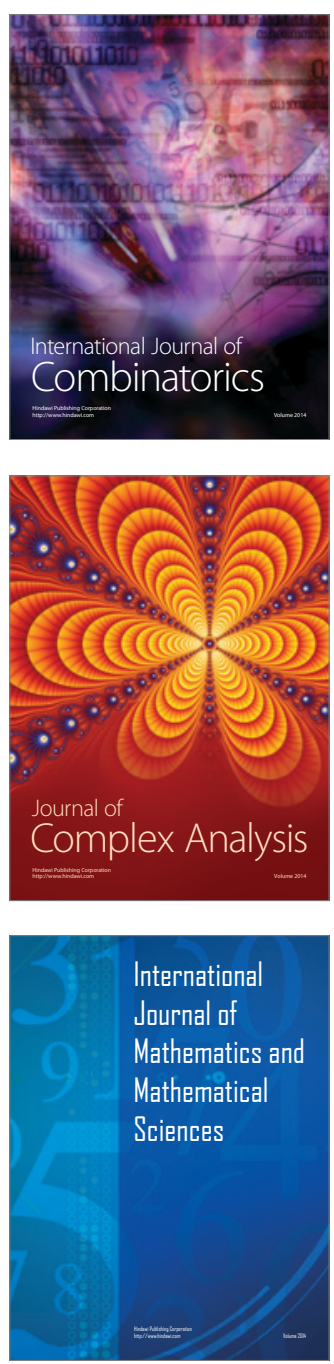
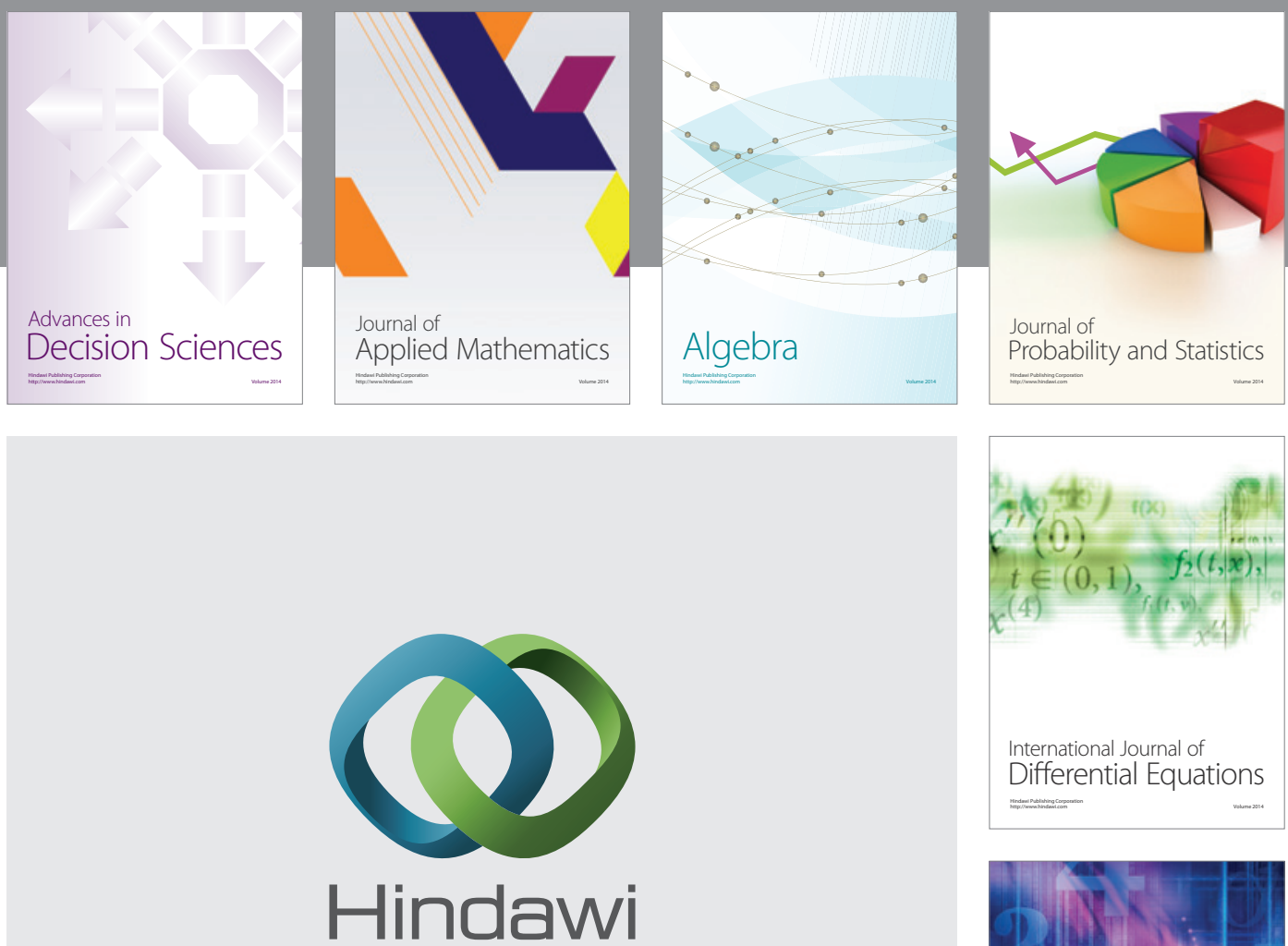

Submit your manuscripts at http://www.hindawi.com
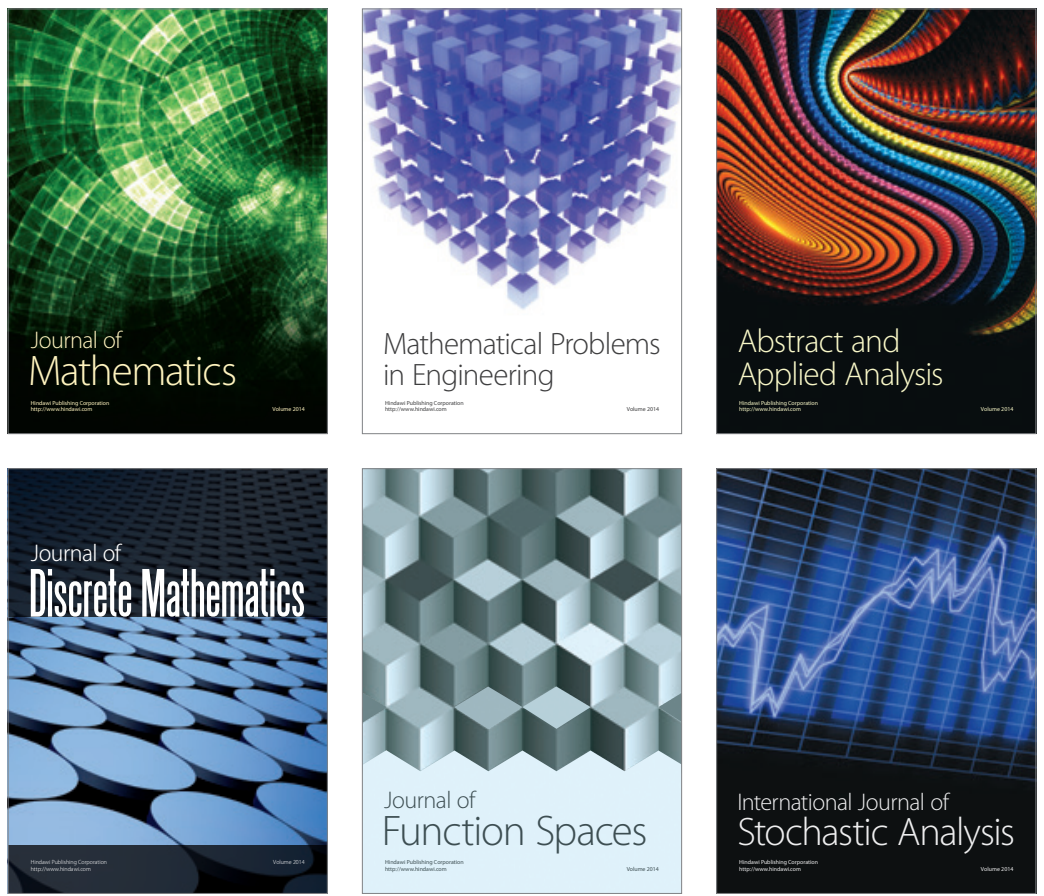

Journal of

Function Spaces

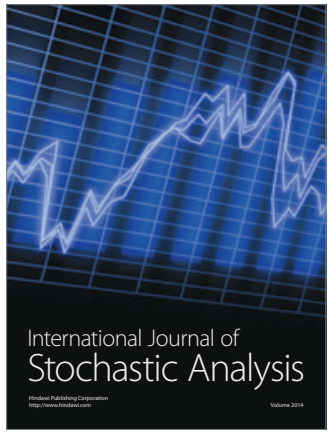

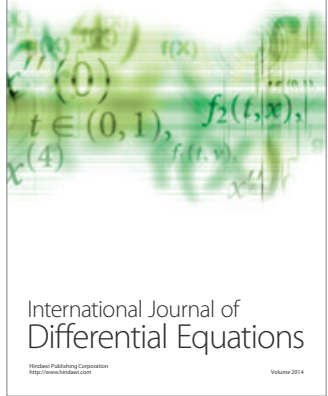
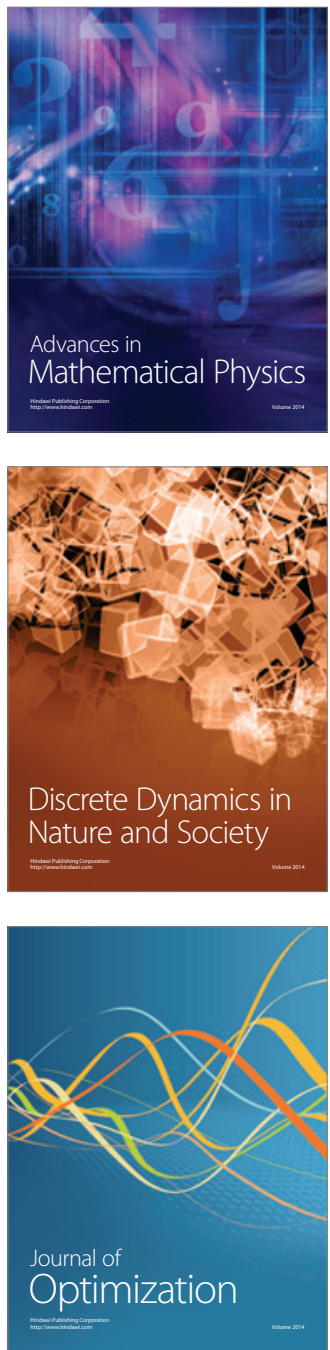